\title{
CRIMEN REPETUNDARUM TRESTNÉ ČINY VYDIERANIA PROVINCIÍ (V RÍMSKOM PRÁVE)
}

\section{CRIMEN REPETUNDARUM \\ CRIMINAL ACTS OF PROVINCE'S RACKETEERING \\ (IN ROMAN LAW)}

\author{
Blažena Antalová \\ Univerzita Pavla Jozefa Šafárika v Košiciach, Právnická fakulta
}

https://doi.org/10.33542/SIC2019-2-01

\begin{abstract}
ABSTRAKT
$V$ poslednom období rímskej republiky dochádzalo k častým prípadom vydierania provincii ich miestodržitel’mi. Rímsky štát sa ich pokúsil odstránit’ prijatím asi 10 zákonov, ktoré takéto činy trestali. Ciel'om príspevku nebolo analyzovat' všetky zákony, vzt'ahujúce sa na úpravu vydierania, ale zamerat' pozornost' len na niektoré z nich, ktoré podl'a názoru autorky najvýznamnejšie zasiahli do vývoja trestného práva republikánskeho obdobia. Príspevok poukázal, ako sa v priebehu vývoja menila skutková podstata tohto trestného činu, akými zmenami prešlo zloženie orgánov stíhajúcich vydieranie a ako sa menil aj charakter trestov za tieto činy.
\end{abstract}

\begin{abstract}
In the final period of Roman republic gave out to periodic cases of province racketeering carried ou by their governors. Roman state make an attempt to eliminated it by acceptance approximately 10 laws which punished these offences. Purpose of this contribution is not analysed all laws relating to legal regulation of this offence, but to focus attention only on selected ones which according to author's opinion predominantly influenced development of criminal law in the Roman republic. The contribution point out that facts of the crime during development was changed - in particular changes in law courts which prosecuted these offences and accordingly, changes of penalties for these criminal acts.
\end{abstract}

\section{I. ÚVOD}

V poslednom období republiky v súvislosti s rozšírením Ríma o nové územia - provincie, ako aj s celkovou politickou, hospodárskou a sociálnou situáciou dochádzalo k častým prípadom vydierania provinčného obyvatel'stva či celých provincií miestodržitel'mi, ktorí zneužívali svoje legálne právomoci na úkor provinčného obyvatel'stva, čo samozrejme vyvolávalo nespokojnost' obyvatel'stva.

Rímsky štát sa preto pokúsil odstránit' nepokoje v provinciách a vyriešit' tieto problémy prijatím celého radu zákonov, ktoré by takéto činy trestali. 
Pre ich potrestanie zriad'oval nové, dovtedy neznáme orgány - určoval, kto mohol byt' ich členom; detailizoval podmienky stíhania - kto mohol byt' žalobcom a žalovaným; konkretizoval sankcie za ne.

V priebehu vývoja došlo k prijatiu viacerých zákonov proti vydieraniu, sprenevere či úplatkárstvu, ktorých sa dopustili magistráti v provinciách, pozdejšie aj iné osoby.

Pod vydieraním pri výkone úradnej moci možno chápat' neoprávnené privlastňovanie si vecí či peňazí, ktorých sa dopúšt’ali miestodržitelia na provinčnom obyvatel'stve či dokonca na celých provinciách.

Neskôr sa pod tento čin zahŕňali aj prípady prijatia úplatku akoukol'vek úradnou osobou, napr. sudcom, dokonca aj svedkom.

Tresty za tento trestný čin v priebehu vývoja boli rôznorodé: od simplum - vrátenie peňazí cez zostrenie na 2-4 násobok neoprávnene získanej sumy; v t’ažších prípadoch na exilium, či stratu politických práv - odsúdený sa nemohol stat' magistrátom, sudcom, ...1, alebo odsúdenému hrozila strata členstva v senáte.

Príspevok je zameraný na jeden z trestných činov, ktorým slovenská a česká právna romanistika doteraz venovala len malú pozornost'. Z autorov, ktorí sa ním zaoberajú je potrebné spomenút' predovšetkým prof. M. Skřejpka, ale aj doc. V. Vranu, či M. Frýdka...2

Jeho ciel'om je podat' stručný pohl'ad, ako sa v priebehu republiky menila právna úprava vydierania, a to predovšetkým za pomoci historicko-právnej metódy s čo najväčším využitím komparatistiky.

\section{PRÁVNA ÚPRAVA CRIMEN REPETUNDARUM}

Trestný čin vydierania upravovalo počas obdobia republiky asi 10 zákonov. Prvá, aj ked' nie celkom jednoznačná norma, upravujúca vydieranie provincií bolo plebiscitum de repetundis $^{3}$ z r. 204 pred n. 1., zakazujúce prijatie daru správcom provincie ${ }^{4}$.

V d’alšom období pribúdali nové právne normy, zamerané na detailizovanie prípadov vydierania a na ich postih.

\section{Lex Calpurnia}

V súvislosti s narastajúcim počtom prekročenia právomocí rímskych miestodržitelov k nevyhnutnej úprave došlo v r. 149 pred n.l., kedy bola prijatá lex Calpurnia, ako historicky prvý zákon na základe zákonodarnej iniciatívy plebejského tribúna Lucia Calpurnia Pisona ${ }^{5}$, ktorým sa namiesto dovtedajších mimoriadnych porotných súdov so všeobecnou právomocou začali zriad'ovat' stále porotné súdy pre jednotlivé trestné činy.

$\mathrm{Na}$ základe tohto zákona bol zriadený prvý stály porotný súd (quaestio perpetua), ktorý mal stíhat' trestné činy vydierania provinčného obyvatel'stva miestodržitel'mi (crimen repetundarum $)^{6}$.

BARTOŠEK, M.: Encyklopedie římského práva, Academia Praha, 1994, ISBN 80-200-0243-X, s. 155, 276

Ich niektoré štúdie na danú tému pozri v zozname literatúry.

Asi nie ako samostatná právna norma, ale len ako súčast' lex Cincia de donis et muneribus z r. 204 pred. n. 1., Pozri:

SKŘEJPEK, M.: Multiplikace trestních norem v republikánském Římě a její příčiny. In: Právnik 2/1991, s. 173.

$4 \mathrm{~K}$ tomu pozri špeciálnu úpravu z r. 154 pred n.l., ktorá zaviedla quaestio extraordinaria proti bývalému konzulovi L. C. LENTULOVI.

5 VRANA, V.: Crimen repetundis a proces proti G. I. Verrovi, In: Prieniky trestného práva k iným právnym odvetviam a vedným disciplínam., Košice, UPJŠ, 2017, s. 139.

6 Neskôr L. C. Sulla zriadil d’alších 7 stálych porotných súdov na stíhanie aj iných trestných činov. 
Už z takéhoto stručného uvedenia do problematiky vyplýva význam Calpurniovho zákona pre vývoj rímskeho trestného práva- bol prvým zo série zákonov de pecuniis repetundis- stály súdny dvor ním zriadený bol prvým stálym dvorom v dejinách Ríma.

Čo sa týka obsahu zákona- umožňoval obetiam ${ }^{7}$ vydierania zo strany magistrátov získat' náhradu za sumy, o ktoré boli v dôsledku konania rímskych magistrátov, resp. promagistrátov pripravení. $^{8}$

Práve moment zriadenia stáleho súdneho dvora možno označit' za významný prínos pre vývoj trestného práva- aj ked' nemal všetky znaky trestného súdu a možno v ňom nájst' viaceré prvky, dané právu súkromnému.

Jedným z nich bola sankcia za porušenie zákona, ktorá určite nemala typickú trestnú povahu. Znela na simplum, bežne v trestnom práve nepoužívanú. V podstate ani nešlo o trest, ale len o povinnost' odsúdeného zaplatit' simplum (jednoduchú hodnotu)- tj. nahradit' spôsobenú škodu- vrátit' získaný prospech.

Pre nás súčasníkov je dnes t’ažko pochopitel'né, prečo zákon stanovil za jeho porušenie len takúto miernu sankciu. Niektorí právni romanisti to pripisujú charakteru navrhovatel'a zákona, ktorého považujú za „slabú osobu“, neschopnú presadit’ tvrdšie tresty ${ }^{9}$.

Významným ustanovením zákona bolo aj rozhodnutie, kto mal stíhat' tento trestný čin. $\mathrm{V}$ jeho zmysle trestanie vydierania provincií spadalo do kompetencie novozriadeného súdneho dvora (quaestio perpetua), zásadným ale bolo, kto mohol byt' členom tohto orgánu.

Lex Calpurnia stanovila, že ním mohli byt' len senátori. Priznanie pozície senátorov v porote quaestio de pecuniis vyvolalo ale obrovské finančné a politické dopady na d'alší vývoj republiky. Pridel'ovanie kresiel sudcov senátorom sa stalo jedným z prioritných rozporov medzi senátormi a jazdcami $\mathrm{v}$ d’alších desat'ročiach, kedy jazdci neuznávali monopol senátorov, ktoré im priznal Calpurniov zákon. ${ }^{10}$

\section{Lex Acilia}

Ďalším zákonom, ktorý zasiahol do vývoja trestného činu vydierania provincií bola Lex Acilia z roku 123, resp. 122 pred n.1., prijatá na návrh tribúna l’udu M.A. Glabriona. ${ }^{11}$ Predstavovala zásadnú zmenu v potrestaní nepoctivých správcov provincií vo viacerých smeroch:

- Prvým z nich bolo zavedenie zmeny členstva v stálom súdnom dvore (quaestio perpetuae). Kým lex Calpurnia stanovila za jeho členov len senátorov, lex Acilia zaviedla, že členmi už nad'alej nemohli byt' senátori, dokonca ani ich synovia alebo blízki príbuzní, čo samozrejme malo aj politický dosah- viedlo k zoslabeniu pozície senátu najmä vo vzt’ahu $\mathrm{k}$ jazdcom.

Takáto zmena bola celkom logická, lebo správcami provincií boli často senátori, či bývalí senátori, preto by bolo málo pravdepodobné ich odsúdenie členmi poroty, zloženej z členov senátu.

- V súvislosti s porotou lex Acilia zaviedla aj d’alšiu zmenu - jej predsedníctvo odobrala cudzineckému prétorovi ${ }^{12}$ a odovzdala ho špeciálnemu prokurátorovi (praetor de repetundis).

\footnotetext{
7 Obet’ami vydierania v zmysle zákona boli najmä spojenci Ríma a mimorímske „subjekty a národy“. Pozri: GIOVANNINI, A: La lex Calpurnia, le sénat et les alliés de Rome, Cahiers du Centre Gustave Glotz, 2014, vol 25 (http:/archive- ouverte. unige.ch), s. 50.

8 Tamtiež, s. 49.

9 Napr. KOLODKO, P.: Lex Calpurnia de pecuniis repetundis, i jej znaczenie dla ewolucji rzymskiego prawa karnego, In: Zeszyty Prawnicze, UKSW, 11.1(2011), s. 161.

10 GIOVANNINI, A.: cit. Op., s. 50.

11 Ktorý ideovo patril k stúpencom politického reformátora - Gaia Sempronia Graccha.

12 Dovtedy tieto činy spadali do jeho jurisdikcie, lebo jednou zo strán boli obyvatelia provincií (neobčania).
} 
- Zákon sa dotkol aj súkromných osôb. Peregrínom, ktorí oznámili previnilého magistráta priznal rímske občianstvo, ako aj financie, vysúdené v procese ${ }^{13}$.

- Najpodstatnejším zásahom do trestného činu vydierania provincií bolo zostrenie postihu za tento čin. Kým sankcia podl'a lex Calpurnia znela len na simplum (na vrátenie peňazí), ktorá sa v trestnom práve nepoužívala (bola mierna a typická pre súkromné právo), lex Acilia sprísnila sankciu na duplum- na pokutu vo výške dvojnásobku spôsobenej škody- čím sa na rozdiel od predchádzajúcej úpravy stala už skutočným trestom.

V tomto možno vidiet' najpodstatnejší prínos lex Acilia do vývoja trestného práva- zákon zmenil charakter postihu zo súkromného práva na charakter procesu verejného (iudicium publicum $)^{14}$. Pokutu vo výške simplum, chápanú nie ako trest, ale len ako povinnost' zaplatit' spôsobenú škodu zmenila lex Acilia na skutočný trest - povinnost' zaplatit' poškodenému duplum, dvojnásobok spôsobenej škody.

Zákon zasiahol aj do politickej scény rímskej republiky. Zmenil stanovisko k porotcomčlenom stáleho súdneho dvora. Nahradil členov poroty zo senátorského stavu prechádzajúceho systému porotcami mimo tohto stavu.

Takto zmenený obsah zákona mal slúžit' ako politická zbraň ${ }^{15}$ Gaia Graccha proti senátorom ${ }^{16}$ a zabezpečit' podporu jeho stúpencom- jazdcom a to presunutím kontroly súdu, resp. jeho právomocí zo senátorov na jazdcov.

\section{Lex Servilia repetundarum}

Úpravu crimen repetundarum určitým spôsobom z hl'adiska zúčastnených strán ovplyvnil aj zákon, ktorého rogátorom bol Gaius Servilius Glaucia - lex Servilia repetundarum z roku 111 pred n.l.. Tento detailizoval pozície žalobcu a žalovaného.

Okruh žalobcov zúžil - boli nimi len Latinovia. Žalovaní- odsúdení sa stali osobami nečestnými (infames) $)^{17}$, čo malo vplyv aj na ich postavenie v súkromnom práve- postihla ich infamia, čo pre nich znamenalo zníženie občianskej cti a tým aj obmedzenie ich právnej spôsobilosti.

\section{Sullove zákony - lex Cornelia iudicaria, lex Cornelia de repetundis}

Do vývoja trestného práva podstatným spôsobom zasiahol aj Lucius Cornelius Sulla. V roku 82 a 81 pred n. 1. okrem hmotnoprávnej úpravy ovplyvnil aj oblast' trestného procesu - rozšríril počet stálych porotných súdov (quaestiones perpetuae) pre jednotlivé trestné činy.

Podl'a vzoru stáleho porotného súdu na stíhanie trestného činu vydierania provinčného obyvatel'stva miestodržitel'mi (crimen repetundarum), zavedeným v r. 149 pred $\mathrm{n}$. 1 . Calpurniovým zákonom, zriadil d'alších 7 porotných súdov na súdenie aj iných trestných činov, konkrétne pre stíhanie: velezrady (crimen maiestatis), pre spreneveru verejného majetku (crimen peculatus), volebného podplácania (ambitus), vykorist'ovania provincií všeobecne (repetundae), úkladnej vraždy a travičstva (de sicariis et veneficiis), falšovania peňazí a testamentov (de falsis), t’ažkého ublíženia na cti alebo na tele (de iniuriis). ${ }^{18}$

13 „Peniaze majú patrit’ tomu, kto podal žalobu“. Pozri: Lex Repetundarum. In: SKŘEJPEK, M.: Texty ke studiu řimského práva, ORAC, Praha, 2001, s. 93.

14 SKŘEJPEK, M.: Ǩímské právo v datech, C- H- BECK, Praha, 1997, s. 23.

15 SHERWIN- WHITE, A. N.: The Lex Repetundarum and the Political Ideas of Gaius Gracchus, In: The Journal of Roman Studies, Vol. 72 (1982), s. 18

16 Ktorí sa postavili proti jeho reformám.

17 SKŘEJPEK, M.: Ř́mské právo v datech, C- H- BECK, Praha, 1997, s. 24.

18 Počet porotných súdov Sullom neskončil. Augustus ich rozšíril aj o stíhanie násilnictva (de vi) a o prečin proti mravnosti (de adulteriis).

https://doi.org/10.33542/SIC2019-2-01 
L. C. Sulla zásadne ovplyvnil a zmenil aj dovtedajšiu úpravu trestného činu vydierania zákonmi lex Cornelia iudicaria a lex Cornelia de repetundis.

Význam týchto zákonov bol v tom, že Sulla nimi:

- rozšíril koncepciu a počet skutkových podstát crimen repetundarum. Okrem pôvodne protiprávneho konania miestodržitel'ov $\mathrm{v}$ súvislosti $\mathrm{s}$ ich výkonom funkcie $\mathrm{v}$ provinciách stíhal aj nové, nielen v provinciách protiprávne konania - penalizoval každú osobu, ktorá dostala peniaze za rozsudok súdu v akejkol'vek veci ${ }^{19}$,

- s ciel'om ul'ahčit' dokazovanie umožňoval svedčit' aj maloletým ${ }^{20}$,

- v snahe posilnit' moc senátu a vrátit' súdnu moc do jeho právomoci, zmenil obsah Aciliovho zákona ${ }^{21}$ - zákonom lex Cornelia iudiciaria, - pôvodné ustanovenia derogoval a upravil $\mathrm{v}$ prospech senátu. Členovia poroty už nad'alej mohli byt' vyberaní len zo senátorov, ${ }^{22}$

- významným spôsobom zasiahol aj do výšky sankcie. Zákonom lex Cornelia de repetundis z r. 81 pred n. 1. opät' znížil trest za vydieranie z duplum na simplum, čo v podstate malo pretrvat' do konca republiky.

Zníženie sankcie ale viacerí právni romanisti považujú za nepravdepodobné a nezlučitel'né s tvrdou trestnoprávnou politikou Sullu. Podl'a nich by bolo dôveryhodnejšie - vzhl'adom na jeho celkový charakter a politiku - že Sulla sprísnil a nie zmiernil takýto trest. Sú presvedčení, že Sulla dokonca zvýšil peňažný trest z duplum na dva a pol násobok. Ako argument uvádzajú asi historicky najznámejší proces s miestodržitel'om Sicílie Gaiom Liciniom Verresom.

V súvislosti s ním poukazujú na požiadavku oratora, ktorý od obžalovaného žiadal zaplatenie nie skutočne odhadnutej sumy 400000 sesterciov, ale až 1000000 sesterciov, čo v podstate vyjadruje pokutu vo výške dva a pol násobku ${ }^{23}$ hodnoty.

\section{Lex Iulia pecuniis repetundis}

Posledná významná republikánska úprava vydierania je obsiahnutá v Caesarovom zákone lex Iulia repetundis z r. 59 pred n.l. Podl'a väčšiny právnych romanistov bol to v rímskom klasickom práve najviac prepracovaný zákon, ktorý najdetailnejšie a najsystematickejšie upravoval trestné činy vydierania. ${ }^{24}$

Oproti predchádzajúcim úpravám rozšíril prípady vydierania provincií miestodržitel'mi aj o iné spôsoby zneužitia úradnej moci a o osoby, ktoré sa ich dopustili:

„Lege Iulia repetundarum tenetur, qui, cum aliguam potestatem haberet, pecuniam ob iudicandum vel non iudicandum decernendumve acceperit." ${ }^{\text {"25 }}$

„Podl'a lex Iulia o vydieraní je zodpovedný ktokol'vek, kto počas zachovávania akejkol’vek (pozície) moci, prijme peniaze výmenou za to, že rozhodne alebo nerozhodne alebo vynesie rozsudok."

19 SÁRY, P.: The Criminal Reforms of Sulla: In: Publicationes universitatis Miskolcinensis, Sectio Iuridica et Politica, Tomus XXII, Miskolc 2004, s. 125, 126.

20 Tamtiež, s. $125,126$.

21 Ktorý vylučoval pôsobenie senátorov v trestných porotách.

22 ULMANN, J.: Př́íciny a dopady reforem Lucia Cornelia Sully, In: Caro amico: 60 kapitol pro Michala Skřejpka neb Ř́mské právo napríč staletími, Praha, Auditorium 2017, s. 514 a nasl.

23 SÁRY, P.: cit. Op., s. 125, 126.

24 Pozri bližšie napr.: VRANA, V.: Právna úprava trestného činu vydierania provinčného obyvatel'stva v klasickom rímskom práve. In: Melior est aquisitio scientiae negotiatione argenti. Pocta Prof. Ignácovi Antoninovi Hrdinovi, O. Praem.K šedesátym narozeninám, Královská kanonie premonstrátů na Strahově, Praha 2013, s. 358.

25 Macer D 48,11, 3. 
Výraz „ktokol'vek“ použitý právnikom Macerom, upresnil iný právnik - Marcián rozumel ním každého, kto mal verejný úrad, mocenské alebo administratívne postavenie alebo akýkol'vek iný úrad, povinnost' alebo verejné zamestnanie, alebo ak bol zamestnancom ktoréhokol'vek z uvedených. ${ }^{26}$

Zákon rozšíril postih aj na osoby, ktorá sa priamo nezúčastnili vydierania, ale určitým spôsobom sa na nich podiel'ali:

„In comites quoque iudicum ex hac lege iudicium datur". ${ }^{27}$

„Podl'a tohto štatútu rozsudku podliehajú aj spoločníci tých, ktorí vykonávajú súdnu funkciu“.

Zákon stanovil najostrejšie sankcie - trest stúpol až na quadruplum ${ }^{28}$ - pokutu vo výške 4násobku neoprávnene získaného majetku; trestom mohla byt' aj strata členstva v senáte; vyhnanstvo; deportácia na ostrov... ${ }^{29}$

Zo široko koncipovaných ustanovení Caesarovho zákona je zrejmé, že zákon sa na rozdiel od predchádzajúcich úprav vzt’ahoval v podstate na všetky spôsoby zneužitia úradnej moci. Caesar rozšírením postihu asi chcel dosiahnut', aby do budúcnosti došlo k odstráneniu alebo aspoň k zníženiu počtu takýchto činov.

Analýzu uvedených zákonov ${ }^{30}$ možno opriet’ aj o výsledky skúmania A. Lintotta, ktorý v závere jednej zo svojich štúdií ${ }^{31}$ uviedol počet stíhaných trestných činov vydierania od prijatia lex Calpurnia v roku 149 pred n. 1. až po rok 50 pred n. 1.; zverejnil mená obžalovaných miestodržitel'ov; uviedol provincie, v ktorých došlo k vydieraniu; ako aj rozsudky za ne.

A. Lintott v štúdii celkovo ozrejmil 49 konkrétnych prípadov vydierania. Zverejnil mená obžalovaných (miestodržitel'ov), ale niektoré problémy svojho výskumu poskytol s otáznikom - napr. nie celkom presné údaje mal o provinciách, v ktorých došlo k vydieraniu (uviedol 12 provincií, $13 \mathrm{~s}$ otáznikom); nie celkom presné údaje mal aj o rozsudkoch - v štúdii uviedol, že z celkového počtu 49 prípadov 24 rozsudkov bolo absolučných, 20 kondemnačných, o 5 rozsudkoch nemal patričné údaje.

Na prvý pohl'ad by sa mohlo zdat', že za skúmané obdobie približne 100 rokov bol nízky počet podania žalôb zo strany vydieraného provinčného obyvatel'stva. Malý počet podaných žalôb je pre nás možno nepochopitel'ný, vzhl'adom na výhody, ktoré mohol získat' úspešný žalobca (občianstvo a financie). Môžeme sa len domnievat', prečo vydierané obyvatel'stvo nevyužilo vo väčšej miere možnost' bránit' sa proti vydieraniu.

Jedným z dôvodov mohla byt' podl'a môjho názoru aj neistota a strach z rozsudku. ${ }^{32}$ V prípade neúspešného rozsudku by sa situácia žalobcu možno ešte zhoršila, preto obyvatel'stvo sa radšej uspokojilo so skutočným stavom a nepokúsilo sa riešit' svoje problémy žalobami.

\footnotetext{
26 Marc. D 48,11,1. Zákon ale umožnil výnimku v prípadoch, kedy bolo legitímne prijímat' veci, napr. od bratrancov alebo pokrvných príbuzných užšieho stupňa alebo od manželky (D 48,11,1,1).

27 Macer D 48, 11, 5.

28 Bartošek, M.: cit. Op., s. 204.

29 Macer D 48, 11, 7, 3.

30 Okrem nich sa skúmanej problematiky týkala aj lex Caecilia z r. 154 pred n. 1.; senatusconsultum Calvisianum, (pozri FRÝDEK, M.: „Čtyři řeči o římské společnosti - dopady zrušení Oppiova sumptuárního zákona na repetundární zločiny u Tacita a Livia“, In: ACTA JURIDICA OLOMOUCENSIS - VOL. IV (X) - No. 6 (2009), s. 294.

31 LINTOTT, A.: The leges de repetundis and Associate Measures under the Republic, In: ZSS, s. 209-212.

32 Tento strach bol asi opodstatnený, lebo z celkového počtu 49 rozsudkov bolo len 20 odsudzujúcich - kondemnačných
} 


\section{ZÁVER}

Vývoj trestnosti vydierania provincií bol značne zložitý, upravený počas republiky približne 10 zákonmi, z ktorých každý z nich určitým spôsobom modifikoval predchádzajúci tým, že:

- rozšíril počet skutkových podstát od pôvodného stíhania miestodržitel'ov v provinciách až po penalizáciu každej osoby, ktorá dostala peniaze za rozsudok súdu v akejkol’vek veci.

- menilo sa nimi zloženie členov poroty, stíhajúcej tento trestný čin (senátori-jazdci), čo malo aj politický dopad na vývoj republiky

- predsedníctvo poroty bolo namiesto cudzineckého prétora zverené do rúk špeciálneho prokurátora (preator de repetundis).

- rozšírila sa trestnost' aj na senátorov

- zúžil sa okruh žalobcov na Latinov

- úspešným žalobcom bolo priznané rímske občianstvo, ako aj financie, vysúdené v procese.

- najväčšou zvláštnost'ou trestného postihu bol jeho súkromný charakter, prejavujúci sa hlavne v uložených trestoch. Pôvodne trestom bola len jednoduchá náhrada škody (simplum $)^{33}$, ktorá ani nebola vymáhatel'ná trestnou žalobou actio poenalis, ale len prostredníctvom legis actio sacramenti. Takúto miernu sankciu - jednoduchú reštitúciu možno vysvetlit' asi aj tým, že obyvatel'om provincií bol navrhnutý rýchly a lacný proces preto boli vd'ační aj za takúto malú pokutu.

- významným sa nám javí aj k hlavnému trestu pripojenie vedlajších trestov, napr.: infamia (typický trest pre súkromné právo); vylúčenie zo senátu; zákaz uchádzat' sa v budúcnosti o zastávanie postu magistrátov; vyhnanstvo ...

- trest bol rozšírený aj na osoby, ktoré sa priamo nezúčastnili vydierania, ale určitým spôsobom sa na ňom podiel'ali.

Tieto zmeny boli určite vyvolané celkovým politickým dianím v rímskej republike. Navrhovatelia zákonov v snahe posilnit' si mocenské ambície sa nimi snažili eliminovat' svojich odporcov a posilnit' pozície prívržencov, čo sa prejavilo hlavne v zložení členov stáleho súdneho dvora (senátori - jazdci). Priznanie silného statusu senátorom (Calpurniovým a Sullovými zákonmi) alebo jazdcom (Aciliovým zákonom) vyvolávalo ale značné finančné a politické dopady na vývoj republiky. Stalo sa jedným z hlavných rozporov medzi senátormi a jazdcami v poslednom období rímskej republiky.

Celkom na záver možno uviest', že ani značné množstvo republikánskych zákonov nevyriešilo problém vydierania provincií, lebo nadvláda nobility, pre ktorú provincie predstavovali značný zdroj príjmov, trvala nad’alej. Preto zmena si počkala až na d'alšie vývojové obdobie - na principát.

\section{KLUUČOVÉ SLOVÁ}

vydieranie provincií; zodpovednost' miestodržitel’ov; súdne orgány; sankcie.

\section{KEY WORDS}

extortion of provinces; governor accountability; judicial bodies; sanctions.

\section{POUŽITÁ LITERATÚRA}

\section{Pôvodné pramene}

\footnotetext{
33 Neskôr sa síce sankcie zmenili na duplum (lex Acilia zmenila charakter procesu na verejný (iudicium publicum), dokonca až na štvornásobok neoprávnene získaného majetku.
} 
1. Digesta Iustiniani, recognovit T. Mommsen, Berlin, 1922.

2. Iustiniani Institutiones. Preklad: Blaho, P.: Corpus iuris civilis. Justiniánske inštitúcie, Iura Edition, Trnava 2000, ISBN-80-88715-80-6.

3. Lex repetundarum, s. 93. Z r.123 př. n.l. (fragment nápisu CII.I.198) In: Preklad: SKŘEJPEK, M.: Texty ke studiu římskeho práva, ORAC Praha, 2001, ISBN-80-8619932-0.

\section{Literatúra}

1. BARTOŠEK, M.: Encyklopedie římskeho práva. Academia Praha, 1994, ISBN-80-2000243-X.

2. FRÝDEK, M.: „Čtyřri řeči o římské společnosti - dopady zrušení Oppiova sumptuárního zákona na repetundární zločiny u Tacita a Livia“, In: ACTA JURIDICA OLOMOUCENSIS - VOL. IV (X) - No. 6 (2009), s. 287 - 296.

3. GIOVANNINI, A.: La lex Calpurnia, le sénat et les alliés de Rome. Cahiers du Centre Gustave Glotz, 2014, vol. 25, s. 49-68 [(http:/archive-ouverte.unige.ch.

4. KOLODKO, P.: Lex Calpurnia de pecuniis repetundis, i jej znaczenie dla ewolucji rzymskiego prawa karnego, In: Zeszyty Prawnicze, UKSW, 11.1(2011). Dostupné na http://dx.doi.org/10.21697/zp.2011.11.1.08.

5. LINTOTT, A.: The leges de repetundis and Associate Measures Under the Republik, In: ZSS, s. 162-212. Dostupné na : https://doi.org/10.7767/zrgra.1981.98.1.162.

6. SÁRY, P.: The Criminal Reforms of Sulla, In: Publicationes universitatis Miskolcinensis, Sectio Iuridica et Politica, Tomus XXII, Miskolc, 2004, s. 123-139.

7. SHERWIN-WHITE, A. N.: The Lex Repetundarum and the Political Ideas of Gaius Gracchus. In: The Journal of Roman Studies, Vol. 72 (1982), s. 18-31. Dostupné na :https://doi.org/10.2307/299113.

8. SKŘEJPEK, M.: Ř́mske právo v datech, C. H. BECK, Praha, 1997.

9. SKŘEJPEK, M.: Multiplikace trestních norem v republikánském Ř́mě a její příčiny. In: Právnik 2/1991, s. 166-178.

10. ŠKKŘEJPEK, M.: Pokuty v trestním právu v období římské republiky. In: Význam peňazí vo vývoji rímskeho práva, PF UPJŠ v Košiciach, 2001, s. 20-25.

11. ULlMANN, J.: Př́činy a dopady reforem Lucia Cornelia Sully. In: Caro amico: 60 kapitol pro Michala Skřejpka neb Ř́mske právo napríč staletími, Praha, Auditorium, 2017, s. 510-518.

12. VRANA, V.: Právna úprava trestného činu vydierania provinčného obyvatel'stva $\mathrm{v}$ klasickom rímskom práve. In: Melior est aquisitio scientiae negotiatione argenti - pocta prof. Ignácovi Antoninovi Hrdinovi k 60. narodeninám, Praha, Královská kanonie premonstrátů na Strahově, 2013, ISBN-9788026038207, s. 353-359.

13. VRANA, V.: Crimen repetundis a proces proti G. L. Verrovi. In: Prieniky trestného práva $\mathrm{k}$ iným právnym odvetviam a vedným disciplínam, Košice UPJŠ, 2017, ISBN9788081524936, s. 137-144.

\section{KONTAKTNÉ ÚDAJE AUTORA:}

doc. JUDr. Blažena Antalová, CSc.

docentka na Katedre dejín štátu a práva

Univerzita Pavla Jozefa Šafárika v Košiciach, Právnická fakulta

Kováčska 30, 04001

Telefón: 055/2344132

E-mail: blazena.antalova@upjs.sk 